\title{
PENGEMBANGAN KURIKULUM BERBASIS MULTI PENDEKATAN
}

\author{
Oleh: \\ Nur Fauzi ${ }^{1}$ \\ Email: fauzipalestin@gmail.com
}

\begin{abstract}
There are five opinions of various approaches to curriculum development. First, according to Muhaimin there is divided into four types namely: Academicapproaches, humanistic, technological, and reconstructionis approaches.Secondly, according to Wina Sanjaya, it is divided into two approaches namely top-down and grass-roots approachesThirdly, according to H.M. Ahmad is divided into two approaches namely approaches thatare oriented towards subject matter, approaches that are oriented towards teaching objectives. Fourth, according to Zainal Arifin, it is divided into fifeapproaches, namely: competency, system, value clarification, comprehensive, and problem-centered approach.Fifth, according to Abdullah Idi, it is divided into threeapproaches, namely: approaches that are oriented to subject matter, material organization patterns, accountability.From various approaches, it can be concluded that the most widely used in developing curriculum is the student-oriented approach and the academic subject approach (oriented towards teaching material)
\end{abstract}

Keywords: development, curriculum, aproach

\section{Pendahuluan}

Kurikulum adalah seperangkat rencana dan pengaturan yang mengenai tujuan, isi dan bahan pelajaran serta cara-cara yang digunakan sebagai pedoman penyelenggaraan kegiatan pembelajaran untuk mencapai tujuan pendidikan tertentu. Sedangkan pengembangan kurikulum merupakan bagian yang esensial dalam proses pendidikan. Sasaran yang dicapai bukan semata-mata memproduksi bahan pelajaran melainkan lebih dititikberatkan untuk meningkatkkan kualitas pendidikan. Pengembangan kurikulum merupakan proses faktor yang harus dipertimbangkan dalam pengembangan kurikulum. Karena pengembangan kurikulum merupakan

${ }^{1}$ Dosen Sekolah Tinggi Agama Islam (STAI) Syaichona Moh. Cholil Bangkalan 
alat untuk membantu guru dalam melakukan tugasnya mengajarkan bahan, menarik minat dan memenuhi kebutuhan masyarakat.

Kurikulum merupakan alat untuk mencapai tujuan pendidikan yang dinamis. Oleh karenanya kurikulum harus selalu dikembangkan dan disempurnakan agar sesuai dengan laju perkembangan ilmu pengetahuan dan teknologi, serta masyarakat yang sedang membangun. Hal ini dimaksudkan agar hasil pengembangan kurikulum tersebut sesuai dengan minat, bakat kebutuhan peserta didik, lingkungan, kebutuhan daerah, sehingga dapat mempelancar program pendidikan salam rangka perwujudan dan pencapaian tujuan pendidikan nasional.

Dalam studi tentang kurikulum sering dipertanyakan jenis pendekatan yang dipergunakan dalam pembahasan atau penyusunan kurikulum tersebut. Penggunaan suatu jenis pendekatan (approach) atau orientasi pada umumnya menentukan bentuk dan pola yang dipergunakan oleh kurikulum. ${ }^{2}$ Dalam hal ini, pendekatan dapat diartikan sebagai titik tolak atau sudut pandang seseorang terhadap suatu proses tertentu. Istilah pendekatan merujuk pada pandangan tentang terjadinya suatu proses yang sifatnya masih sangat umum. Dengan demikian, pendekatan pengembangan kurikulum merujuk pada titik tolak atau sudut pandang secara umum tentang proses pengembangan kurikulum.

\section{Pembahasan}

\section{Pengertian Pendekatan Pengembangan Kurikulum}

Pendekatan adalah cara kerja dengan menerapkan strategi dan metode yang tepat dengan mengikuti langkah-langkah pengembangan yang sistematis agar memperoleh kurikulum yang lebih baik. Pendekatan dapat diartikan sebagai titik tolak atau sudut pandang seseorang terhadap suatu proses tertentu. Istilah pendekatan merujuk kepada pandangan tentang terjadinya suatu proses yang sifatnya masih sangat umum. Dengan demikian, pendekatan pengembangan kurikulum menunjuk pada titik

${ }^{2}$ Oemar hamalik, Dasar-dasar Pengembangan Kurikulum (Bandung: PT. Remaja Rosdakarya, 2008), 31. 
tolak atau sudut pandang secara umum tentang proses pengembangan kurikulum.

\section{Pendekatan-Pendekatan Pengembangan Kurikulum}

Langkah selanjutnya yang perlu diperhatikan ialah teknik pendekatan kurikulum yang serasi setelah mempertimbangkan keempat determinan ialah asas filosofis, sosiologis psikologis dan hakikat ilmu pengetahuan yang merupakan pegangan umum. ${ }^{3}$ Namun masih perlu lagi pegangan yang lebih rinci, yakni:

a. Memilih pendekatan kurikulum yang serasi untuk mendesain kurikulum dengan mempertimbangkan keempat determinan itu.

b. Berdasarkan pendekatan yang disiplin, menentukan mata pelajaran/mata kuliah yang akan disajikan, beserta bidang dan rangkaiannya yang dianggap dapat mencapai tujuan lembaga pendidikan itu. ${ }^{4}$

Berbagai pendekatan kurikulum yang ada dewasa ini menurut beberapa tokoh. Menurut Muhaimin, pendekatan kurikulum diklasifikasikan sebagai berikut.

\section{a. Pendekatan Subjek Akademis (bidang studi)}

Pada pendekatan subjek akademik menggunakan bidang studi atau mata pelajaran sebagai dasar organisasi kurikulum, misalnya: matematika, sains, sejarah, geografi, atau IPA, IPS, dan sebagainya seperti yang lazim didapati dalam sistem pendidikan sekarang ini disemua sekolah dan perguruan tinggi. ${ }^{5}$ Prioritas pendekatan ini adalah mengutamakan sifat perencanaan program dan juga mengutamakan penguasaan bahan dan proses dalam disiplin ilmu tertentu. 6

Kurikulum disajikan dalam bagian-bagian ilmu pengetahuan, mata pelajaran yang diintregasikan. Ciri-ciri ini berhubungan dengan maksud,

\footnotetext{
${ }^{3}$ H. Fachruddin, Teknik Pengembangan Kurikulum Penagajaran Bahasa Arab, (Yogyakarta: Global Pustaka Utama, 2006), 94.

${ }^{4}$ S. Nasution, Kurikulum dan Pengajaran, (Jakarta: Bumi Aksara, 1995), 43.

${ }^{5}$ S. Nasution, Kurikulum dan Pengajaran (Jakarta: Bumi Aksara, 1989), 43.

${ }^{6}$ Abdullah Idi, Pengembangan Kurikulum Teori dan Prakteki, (Yogyakarta: Ar-Ruzz Media, 2007), 190.
} 
metode, organisasi dan evaluasi. Pendekatan subjek akademis dalam menyusun kurikulum atau program pendidikan didasarkan pada sistematisasi disiplin ilmu masing-masing. Para ahli akademis terus mencoba mengembangkan sebuah kurikulum yang akan melengkapi peserta didik untuk masuk ke dunia pengetahuan, dengan konsep dasar dan metode untuk mengamati, hubungan antara sesama, analisis data, dan penarikan kesimpulan. Pengembangan kurikulum subjek akademis dilakukan dengan cara menetapkan lebih dahulu mata pelajaran/mata kuliah apa yang harus dipelajari peserta didik, yang diperlukan untuk persiapan pengembangan disiplin ilmu. ${ }^{7}$

Setiap mata pelajaran jika diperhatikan dapat diketahui adanya:

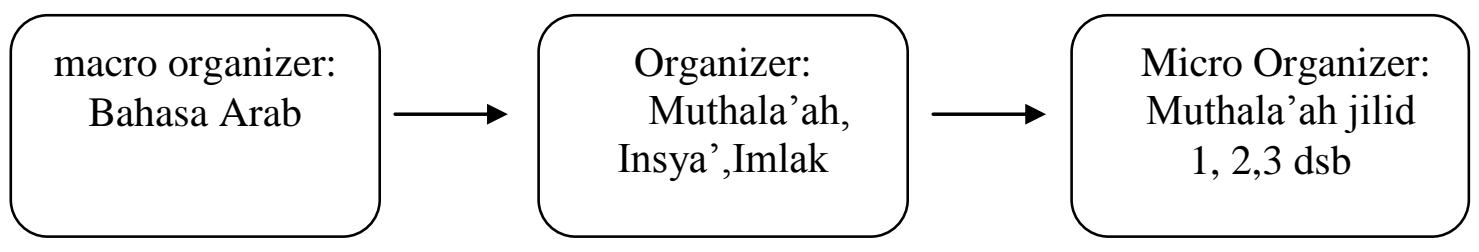

Titik pendekatan di bidang ini ialah murid menguasai setiap mata pelajaran yang disajikan sebagai disiplin ilmu tertentu. Pendekatan di atas adalah pendekatan yang paling mudah dan sederhana karena masingmasing mata pelajaran telah jelas batas-batasnya.Antara bahasa Arab dan Inggris, sejarah dan matematika, geografi dan kesenian jelas yaitu, masingmasing mempunyai ruang lingkup tersendiri. ${ }^{8}$

Sekurang-kurang ada tiga pendekatan dalam perkembangan Kurikulum Subjek Akademis. ${ }^{9}$ Pendekatan pertama, melanjutkan pendekatan struktur pengetahuan. Murid-murid belajar bagaimana memperoleh dan menguji fakta-fakta dan bukan sekadar mengingat-ingatnya.

\footnotetext{
${ }^{7}$ Muhaimin, Pengembangan Kurikulum Pendidikan Agama Islam di Sekolah, Madrasah dan Perguruan Tinggi.( Jakarta: PT. Raja Grafindo Persada,2010), 140.

${ }^{8}$ H. Fachruddin, Teknik Pengembangan Kurikulum Penagajaran Bahasa Arab, (Yogyakarta: Global Pustaka Utama, 2006), 94.

${ }^{9}$ Nana Syaodih sukmadinata, Pengembangan Kurikulum: Teori dan Praktek (Bandung: PT. Remaja Rosdakarya, 2004), 83-84.
} 
Pendekatan kedua, adalah studi yang bersifat integratif. Pendekatan ini merupakan respon terhadap perkembangan masyarakat yang menuntut model-model pengetahuan yang lebih komprehensif-terpadu. Pelajaran tersusun atas satuan-satuan pelajaran, dalam satuan-satuan pelajaran tersebut batas-batas ilmu menjadi hilang. Pengorganisasian tema-tema pengajaran didasarkan atas fenomena-fenomena alam, proses kerja ilmiah dan problema-problema yang ada.

Pendekatan ketiga, adalah pendekatan yang dilaksanakan pada sekolah-sekolah fundamentalis. Mereka tetap mengajar berdasarkan matamata pelajaran dengan menekankan membaca, menulis, dan memecahkan masalah-masalah matematis. Pelajaran-pelajaran lain seperti ilmu kealaman, ilmu sosial, dan lain-lain dipelajari tanpa dihubungkan dengan kebutuhan praktis pemecehan masalah dalam kehidupan.

Dalam pendekatan pengembangan kurikulum ada mempunyai ciriciri sebagai berikut. ${ }^{10}$

1) Tujuan

Tujuan kurikulum subjek akademik adalah pemberian pengetahuan yang solid serta melatih para siswa menggunakan ide-ide dan proses "penelitian". Para siswa harus belajar mengunakan pemikiran dan dapat mengontrol dorongan-dorongannya, sehingga diharapkan siswa mempunyai konsep dan cara yang terus dapat dikembangkan di masyarakat yang lebih luas.

2) Metode

Metode yang banyak digunakan dalam pendekatam subjek akademik adalah pendekatan metode ekspositori dan inkuiri. Ide-ide diberikan guru kemudian dielaborasi (dilaksanakan) siswa sampai mereka kuasai. Dalam materi disiplin ilmu yang diperoleh, dicari berbagai masalah penting, kemudian dirumuskan dan dicari cara pemecahannya.

3) Organisasi isi

Ada beberapa pola organisasi isi (materi pelajaran) kurikulum subjek akademik. Pola-pola organisasi yang terpenting di antaranya:

${ }^{10}$ Nana Syaodih sukmadinata, Pengembangan ...., h. 84-85.

Volume 11 Nomor 1 Maret 2020 
a) Correlated curriculum, adalah pola organisasi materi atau konsep yang dipelajari dalam suatu pelajaran dikorelasikan dengan pelajaran lainnya.

b) Unified atau concentrated, adalah pola organisasi bahan pelajaran tersusun dalam tema-tema pelajaran tertentu, yang mencakup materi dari berbagai pelajaran disiplin ilmu.

c) Intregrated curriculum, kalau dalam unified masih tampak warna displin ilmunya, maka dalam pola yang integrated warna disiplin ilmu tersebut sudah tidak kelihatan lagi. Bahan ajar diintegrasikan dalam suatu persoalan, kegiatan atau segi kehidupan tertentu.

d) Problem solving curriculum, adalah pola organisasi isi yang beriisi topik pemecahan masalah sosial yang dihadapi dalam kehidupan dengan menggunakan pengetahuan dan ketrampilan yang diperoleh dari berbagai mata pelajaran atau disiplin ilmu.

4) Evaluasi

Kurikulum subjek akademik menggunakan bentuk evaluasi yang bervariasi disesuaikan dengan tujuan dan sifat mata pelajaran. Dalam bidang studi humaniora lebih banyak digunakan bentuk uraian (essay test) dari tes objektif. Karena bidang studi ini membutuhkan jawaban yang merefleksikan logika, koherensi, dan integrasi secara menyeluruh. Kelemahan pendekatan ini adalah kegagalan dalam memberikan perhatian kepada yang lainnya, dan melihat bagaimana isi dan disiplin dapat membawa mereka pada permasalahan kehidupan modern yang kompleks, yang tidak dapat dijawab oleh hanya satu ilmu saja. ${ }^{11}$

\section{b. Pendekatan Humanistik}

Pendekatan humanistik dalam pengembangan kurikulum bertolak dari ide "memanusiakan manusia". Penciptaan konteks yang akan memberi peluang manusia untuk menjadi lebih human, untuk mempertinggi harkat

\footnotetext{
${ }^{11}$ Muhaimin, Pengembangan Kurikulum Pendidikan Agama Islam di Sekolah, Madrasah dan Perguruan Tinggi.( Jakarta: PT. Raja Grafindo Persada,2010), 140.
} 
manusia merupakan dasar filosofi, dasar teori, dasar evaluasi dan dasar pengembangan program pendidikan. ${ }^{12}$

Pada pendekatan humanistik berpusat pada siswa, jadi student centered, dan mengutamakan perkembangan afektif siswa sebagai prasyarat dan sebagai bagian integral dari proses belajar. Menurut Somantrie dalam Abdullah Idi, bahwa pada pendekatan humanistik prioritasnya adalah pengalaman belajar yang diarahkan terhadap tanggapan minat, kebutuhan dan kemampuan anak. ${ }^{13}$

Permasalahan yang perlu disadari adalah bahwa materi bukanlah tujuan. Dengan demikian, keberhasilan pendidikan tidak semata-mata diukur dengan lancarnya proses transmisi nilai-nilai (dalam hal ini materi pelajaran yang terformat dalam kurikulum), melainkan lebih dari sekadar hal itu. Pendidikan humanistik menganggap materi pendidikan lebih merupakan sarana, yakni sarana untuk membentuk pematangan humanisasi peserta didik, jasmani dan ruhani secara gradual. ${ }^{14}$

Jadi dari hal tersebut dapatlah kita pahami bahwa pada pendekatan humanistik tujuan dari pendidikan itu bukan hanya pada nilai-nilai yang dapat dicapai pesera didik tapi lebih kepada pembentukan perubahan pada peserta didik, baik secara jasmani maupun rohani.

Selanjutnya siswa hendaknya diturutsertakan dalam penyelenggaraan kelas dan keputusan instruksional. Siswa hendaknya turut serta dalam pembuatan, pelaksanaan, dan pengawasan peraturan sekolah. Siswa hendaknya diperbolehkan memilih kegiatan belajar, dan siswa boleh membuktikan hasil belajarnya melalui berbagai macam karya atau kegiatan.

Dalam kurikulum humanistik, guru diharapkan dapat membangun hubungan emosional yang baik dengan peserta didiknya, untuk

\footnotetext{
${ }^{12}$ Muhaimin, Pengembangan Kurikulum......, 142.

${ }^{13}$ Abdullah Idi, Pengembangan Kurikulum: Teori dan Praktik ( Jakarta: Gaya Media Pratama, 1999), 130.

${ }^{14}$ Baharuddin \& Makin, Pendidikan Humanistik:Konsep, Teori, dan Aplikasi Praktis dalam Dunia Pendidikan (Jogjakarta: Ar-Ruzz Media, 2007), 192.
} 
perkembangan individu peserta didik itu selanjutnya. Oleh karena itu, peran guru yang diharapkan adalah sebagai berikut: ${ }^{15}$

1. Mendengar pandangan realitas peserta didik secara komprehensif

2. Menghormati individu peserta didik, dan

3. Tampil alamiah, otentik, tidak dibuat-buat.

Tugas guru dalam kurikulum humanistik adalah menciptakan situasi yang permisif dan mendorong peserta didik untuk mencari dan mengembangkan pemecahan sendiri. Tujuan pengajaran adalah memperluas kesadaran diri sendiri dan mengurangi kerenggangan dan keterasingan dari lingkungan. ${ }^{16}$

Dari sini jelaslah bahwa pendekatan pengembangan kurikulum humanistik ini mengaharapkan perkembangan diri siswa sehingga dapat menemukan kepribadiannya yang hidup ditengah-tengah masyarakat.

Pendekatan pengembangan kurkulum mempunyai beberapa ciri-ciri, yakni: ${ }^{17}$

1) Tujuan

Tujuan pendidikannya adalah oroses perkembangan pribadi yang dinamis yang diarahkan pada pertumbuhan, integritas, dan otonomi kepribadiaan, sikap yang sehat terhadap diri sendiri, orang lain, dan belajar. Semuanya itu merupakan bagian dan cita-cita perkembangan manusia yang teraktualisasi (self actualizing person). Seseorang yang telah mampu mengaktualisasikan diri adalah orang yang telah mencapai keseimbangan (harmoni) perkembangan seluruh aspek pribadinya baik aspek kognitif, estetika, maupun moral.

2) Metode

Pengembangan kurikulum humanistik menuntut hubungan emosional yang baik antara guru dan siswa. Karenanya, menuntut kemampuan guru untuk memilih metode pembelajaran yang dapat menciptakan hubungan yang hangat antara guru dengan murid, antara murid dengan murid, dapat memberikan dorongan agar saling percaya. Dalam

${ }^{15}$ Oemar Hamalik, Dasar-dasar Pengembangan Kurikulum (Bandung: PT. Remaja Rosdakarya, 2008), 144.

${ }^{16}$ Siti Halimah, Telaah Kurikulum, 160.

${ }^{17} \mathrm{Ibid}, 160-161$

Volume 11 Nomor 1 Maret 2020

Approved: 02-01-2020, Accepted: 15-02-2020, Submitted: 09-03-2020 
kegiatan pembelajaran guru tidak boleh memaksakan sesuatu yang tidak disenangi oleh peserta didik.

3) Organisasi Isi

Kurikulum humanistik harus mampu memberikan pengalaman yang menyeluruh, bukan pengalaman yang terpenggal-penggal.

4) Evaluasi

Evaluasi kurikulum humanistik berbeda dengan evaluasi pada umumnya, yang lebih ditekankan pada hasil akhir atau produk. Sebaliknya, evaluasi kurikulum humanistik lebih menekankan pada proses yang dilakukan. Kurikulum ini melihat kegiatan sebagai sebuah manfaat untuk peserta didik masa depan. Kelas yang baik akan menyediakan berbagai pengalaman untuk mambantu peserta didik menyadari potensi mereka dan orang lain, serta dapat mengembangkannya.

Pada kurikulum ini, guru diharapkan mengetahui respon peserta didik terhadap kegiatan mengajar. Guru juga diharapkan mengamati apa yang sudah dilakukannya, untuk melihat umpan balik setelah kegiatan belajar dilakukan. Sebagai suatu hal yang alamiah, kurikulum humanistik memilki beberapa kelemahan, seperti: ${ }^{18}$

1) Keterlibatan emosional tidak selamanya berdampak positif bagi perkembangan individual peserta didik,

2) Meskipun kurikulum ini sangat menekankan individu peserta didik, pada kenyataannya di setiap program terdapat keseragaman peserta didik,

3) Kurikulum ini kurang memperhatikan kebutuhan masyarakat secara keseluruhan, dan

4) Dalam kurikulum ini, prinsip-prinsip psikologis yang ada kurang terhubungkan.

\section{c. Pendekatan Teknologis}

${ }^{18}$ Oemar Hamalik, Dasar-dasar Pengembangan Kurikulum,(Bandung: PT. Remaja Rosdakarya, 2008), 145. 
Perspektif teknologi sebagai kurikulum ditekankan pada efektifitas program metode dan material untuk mencapai suatu manfaat dan keberhasilan. Teknologi mempengaruhi kurikulum dalam dua cara, yaitu: aplikasi dan teori. Aplikasi teknologi merupakan suatu rencana penggunaan beragam alat dan media, atau tahapan basis instruksi. Sebagai teori, teknologi digunakan dalam pengembangan dan evaluasi material kurikulum dan instruksional. ${ }^{19}$

Pandangan pertama menyatakan bahwa pemanfaatan teknologi lebih diarahkan pada bagaimana mengajarnya, bukan apa yang diajarkan. Sementara pandangan kedua menyatakan bahwa teknologi diarahkan pada penerapan tahapan instruksional.

Penerapan teknologi dalam bidang pendidikan khususnya kurikulum adalah dalam dua bentuk, yaitu bentuk perangkat lunak (software) dan perangkat keras (hardware). Penerapan teknologi perangkat keras dalam pendidikan dikenal sebagai teknologi alat (tools technology), sedangkan penerapan teknologi perangkat lunak disebut juga teknologi sistem (system technology). ${ }^{20}$

Teknologi pendidikan dalam arti teknologi alat, lebih menekankan kepada penggunaan alat-alat teknologi untuk menunjang efisiensi dan efektifitas pendidikan. Kurikulumnya berisikan rencana-rencana penggunaan berbagai alat dan media, juga model-model pengajaran yang banyak melibatkan penggunaan alat. Contoh-contoh model pengajaran tersebut adalah: pengajaran dengan bantuan film dan video, pengajaran berprogram, mesin pengajaran, pengajaran modul. Pengajaran dengan bantuan komputer, dan lain-lain.

Pendekatan teknologi dalam menyusun kurikulum atau program pendidikan bertolak dari analisis kompetensi yang dibutuhkan untuk melaksanakan tugas-tugas tertentu. Karenanya materi yang diajarkan, kriteria evaluasi sukses, dan strategi belajarnya ditetapkan sesuai dengan analisis tugas (job analysis) tersebut. Contoh penerapannya dalam kurikulum dan hasil belajar, misalnya dalam mata pelajaran PAI, tentang

${ }^{19}$ Oemar Hamalik, Dasar-dasar ..., 148.

${ }^{20}$ Nana Syaodih Sukmadinata, Penegembangan kurikulum:Teori dan praktek, 96.

Volume 11 Nomor 1 Maret 2020

Approved: 02-01-2020, Accepted: 15-02-2020, Submitted: 09-03-2020 
menyajikan pesan pembelajaran tentang shalat, maka dapat dirumuskan sebagai berikut: ${ }^{21}$

1) Kompetensi dasar : mampu melaksanakan shalat

2) Hasil belajar: (a) siswa mampu menjelaskan tata cara shalat yang benar

(b) siswa mampu manghafal dan mmempraktikkan bacaan shalat

3) Indikator:

a) Menjelaskan pengertian shalat

b) Menjelaskan syarat-syarat shalat

c) Menjelaskan rukun shalat

d) Menjelaskan sunnat shalat

e) Menjelaskan hal-hal yang membatalkan shalat

f) Melafalkan bacaan shalat dengan benar

g) Menghafal bacaan shalat

h) Mempraktikan shalat

i) Mau melaksanakan shalat

j) Terbiasa melaksanakan shalat

Dari rumusan kompetensi dasar dan hasil belajar, dan dijabarkan dalam rumusan indikator, maka dapat di ketahui organisasi isi dari pembelajarannya.Dan untuk mengorganisasikan isi dengan baik, diperlukan analisis tugas dann jenjang belajar sesuai dengan kerakteristik pendekatan teknologi.

\section{d. Pendekatan Rekontruksionalisme}

Kurikulum rekonstruksi sosial sangat memperhatikan hubungan kurikulum dengan sosial masyarakat dan politik perkembangan ekonomi. Banyak prinsip kelompok ini yang konsisten dengan cita-cita tertinggi, contohnya masalah hak asasi kaum minoritas, keyakinan dalam intelektual masyarakat umumnya, dan kemampuan menentukan nasib sendiri sesuai arahan yang mereka inginkan.

Pengajaran kurikulum rekonstruksi sosial banyak dilaksanakan di daerah-daerah yang tergolong belum maju dan tingkat ekonominya juga belum tinggi. Pelaksanaan pengajaran ini diarahkan untuk meningkatkan

${ }^{21}$ Siti Halimah, Telaah kurikulum, 162. 
kondisi kehidupan mereka. Sesuai dengan potensi yang ada dalam masyarakat, sekolah mempelajari potensi-potensi tersebut, dengan bantuan biaya dari pemerintah, sekolah berusaha mengembangkan potensi tersebut. Di daerah pertanian misalnya maka sekolah harus mengembangkan bidang pertanian, sementara kalau daerah industri maka yang harus dikembangkan oleh sekolah adalah bidang industri. Sehingga kurikulum tersebut dapat memenuhi kebutuhan masyarakat daerah tersebut.

Kurikulum rekonstruksi sosial bertujuan untuk menghadapkan peserta didik pada berbagai permasalahan manusia dan kemanusian. Para pendukung kurikulum ini yakin, bahwa permasalahan yang muncul tidak harus diperhatikan oleh "pengetahuan sosial" saja, tetapi oleh setiap disiplin ilmu.

Dari pemikiran di atas, maka penyusunan dan pengembangan kurikulum harus bertitiktolak dari problem yang dihadapi dalam masyarakat. Pendekatan kurikulum rekonstrksi sosial ini selain menekan pada isi pembelajaran, sekaligus juga menekankan pada proses pendidikan dari pengalaman belajar. Ini dikarenakan, pendekatan rekonstruksi sosial berasumsi bahwa, manusia adalah makhluk sosial yang sepanjang kehidupannya membutuhkan orang lain, selalu bersama, berinteraksi dan bekerjasama. ${ }^{22}$

Dari pendekatan kurikulum rekonstruksi sosial ini, nantinya diharapkan peserta didik mempunyai tanggung jawab dalam masyarakatnya guna membantu pemerintah dalam perbaikan-perbaikan dalam masyarakatnya yang lebih baik lagi kedepannya.

Adapun pendekatan kurikulum rekonstruksi sosial ini mempunyai ciri-ciri berkenaan dengan: ${ }^{23}$

1) Tujuan

Tujuan utama kurikulum rekonstruksi sosial adalah menghadapkan para peserta didik pada tantangan, ancaman, hambatan-hambatan atau gangguan-gangguan yang dihadapi manusia. Karena itu, tujuan

${ }^{22}$ Siti Halimah, Telaah Kurikulum, h. 164.

${ }^{23}$ Ibid, h. 165-166.

Volume 11 Nomor 1 Maret 2020

Approved: 02-01-2020, Accepted: 15-02-2020, Submitted: 09-03-2020 
program pendidikan setiap tahun berubah. Tantangan-tantangan tersebut merupakan bidang garapan selain bidang studi agama, juga perlu didekati dari bidang-bidang lain seperti ekonomi, sosiologi, ilmu pengetahuan alam, estetika, matematika dan lain-lain.

2) Metode

Tugas guru dalam kegiatan pembelajaran dalam kurikulum rekonstruksi sosial, yaitu: berusaha mencari keselarasan antara tujuantujuan nasional dengan tujuan peserta didik. Dalam melaksanakan kegiatan pembelajaran guru harus dapat membantu para peserta didik untuk menemukan minat dan kebutuhannya.

3) Kegiatan pembelajaran yang dilakukan untuk mencapai tujuan pendidikan dalam persoalan-persoalan tersebut di atas dapat dilakukan dengan menggunakan berbagai metode antara lain: (1) mengadakan survei kritis kepada masyarakat; (2) mengadakan studi banding ekonomi lokal dan nasional; (3) mengevaluasi semua rencana dengan kriteria, apakah telah memenuhi kepentingan sebagian besar orang.

4) Organisasi Isi

Pola organisasi isi kurikulum rekonstruksi sosial disusun seperti roda. Ditengah-tengahnya sebagai poros dipilih sesuatu masalah yang menjadi tema utama dan dibahas secara pleno. Tema-tema tersebut dijabarkan ke dalam sejumlah topik yang dibahas dalam diskusi kelompok, latihan-latihan, kunjungan dan lain-lain. Topik-topik dengan berbagai kelompok ini merupakan jari-jari. Semua kegiatan jari-jari tersebut dirangkum menjadi satu kesatuan sebagai bingkai.

5) Evaluasi

Dalam kegiatan evaluasi para peserta didik dilibatkan. Keterlibatan para peserta didik terutama dalam memilih, menyusun, dan menilai bahan yang akan diujikan. Soal-soal yang akan diujikan terlebih dahulu diuji untuk menilai ketepatan maupun keluasan isinya. Selain itu juga untuk menilai keampuhannya dalam menilai pencapaian tujuan-tujuan pembangunan kehidupan keberagaman masyarakat yang sifatnya kualitatif. 
Menurut H.M. Ahmad, pendekatan pengembangan kurikulum dibagi dua yaitu:

\section{Pendekatan yang berorientasi pada bahan pelajaran}

Dalam pendekatan ini, pertanyaan pertama yang muncul pada waktu menyusun kurikulum adalah "bahan atau materi apakah yang perlu diberikan/diajarkan kepada murid?" Pendekatan ini di Indonesia diterapkan dalam kurikulum sebelum kurikulum 1975.24

Kelebihan dari pendekatan yang berorientasi pada bahan pelajaran bahwa kita lebih fleksibel/bebas dalam menyusun bahan pelajaran karena kita tidak terikat oleh tujuan yang tegas. Tapi kekurangan dari pendekatan ini adalah:

a. Bahan pelajaran yang kita susun kurang jelas arah dan tujuannya,

b. Sukar dalam mementukan cara (metode) yang sesuai untuk menyajikan bahan tersebut pada murid.

c. Kurang jelas pada segi-segi apa yang akan dinilai pada peserta didik setelah menyelesaikan pelajaran, dan bagaimana cara menilainya. ${ }^{25}$

\section{Pendekatan yang berorientasi pada tujuan pengajaran}

Dalam pendekatan yang kedua ini, pertanyaan yang pertama kali muncul adalah "tujuan-tujuan apakah yang ingin dicapai, atau pengetahuan, keterampilan dan sikap apakah yang kita harapkan akan dimiliki oleh peserta didik setelah menyelesaikan kurikulum ini?26

Sebagai jawaban terhadap pertanyaan tersebut, kemudian dirumuskan tujuan-tujuan dalam bentuk pengetahuan, keterampilan dan sikap yang diharapkan secara jelas. ${ }^{27}$

Atas dasar tujuan-tujuan di atas itulah selanjutnya ditetapkan pokokpokok bahan pelajaran dan kegiatan belajar mengajar, yang semuanya itu diarahkan untuk mencapai tujuan-tujuan yang diinginkan.

\footnotetext{
${ }^{24}$ Pengembangan dan Inovasi Kurikulum, 55-56.

${ }^{25}$ Hendyat Soetopo \& Wasty Soemanto, Pembinaan dan Pengembangan Kurikulum, (Jakarta: Bumi Aksara, 1993), 55-56.

${ }^{26}$ Pengembangan dan Inovasi Kurikulum, 56.

${ }^{27}$ Hendyat Soetopo \& Wasty Soemanto, Pembinaan dan Pengembangan..., 55.
} 
Kelebihan dari pendekatan yang berorientasi pada tujuan pengajaran adalah:

a. Tujuan yang ingin dicapai jelas bagi penyusunan kurikulum

b. Tujuan-tujuan yang jelas tersebut akan memberikan arah di dalam menetapkan metode, jenis-jenis kegiatan, alat yang diperlukan guna mencapai tujuan

c. Tujuan-tujuan yang jelas tersebut juga akan memberikan arah di dalam mengadakan penilaian terhadap hasil yang dicapai

d. Hasil penilaian yang terarah tersebut akan akan membantu penyusunan kurikulum di dalam mengadakan perbaikan-perbaikan yang di perlukan.

Sedangkan kekurangan pada pendekatan ini adalah, kesulitan dalam merumuskan tujuan apa lagi jika tujuan tersebut harus dirumuskan secara khusus. ${ }^{28}$ Atas dasar tinjauan di atas, tampaknya pendekatan yang berorientasi pada tujuan mempunyai lebih banyak segi-segi yang menguntungkan daripada yang merugikan, dibandingkan dengan pendekatan yang berorientasi pada bahan pelajaran.

Menurut Zainal Arifin (2011) dalam bukunya Konsep dan Model Pengembangan Kurikulum, jika dilihat dari aspek perencanaannya ada beberapa pendekatan yang dapat digunakan dalam pengembangan kurikulum, antara lain sebagai berikut. ${ }^{29}$

\section{Pendekatan Kompetensi (Competency Approach)}

Kompetensi adalah jalinan terpadu yang unik antara pengetahuan, keterampilan, sikap dan nilai-nilai yang direfleksikan dalam pola berfikir dan pola bertindak.Pendekatan kompetensi menitikberatkan pada semua ranah, yaitu kognitif, afektif dan psikomotorik. Ciri-ciri pokok pendekatan kompetensi adalah berpikir teratur dan sistematik, sasaran penilaian lebih difokuskan pada tingkat penguasaan, dan kemampuan memperbarui diri (regenerative capability). ${ }^{30}$

\footnotetext{
${ }^{28}$ Ibid, 56.

${ }^{29}$ Zainal Arifin, Konsep dan Model Pengembangan Kurikulum, (Bandung: PT Remaja Rosdakarya, 2012), 113.

${ }^{30}$ Zainal Arifin, Konsep dan Model Pengembangan ..., 113.
} 
Prosedur penggunaan pendekatan ini adalah (a) menetapkan standar kompetensi lulusan yang harus dikuasai oleh para lulusan pada setiap jenis dan jenjang pendidikan, (b) memerinci perangkat kompetensi yang diharapkan dimiliki oleh para lulusan, (c) menetapkan bentuk dan kuantitas pengalaman belajar melalui bidang studi atau mata pelajaran dan kegiatan-kegiatan lainnya yang relevan, (d) mengembangkan silabus. ${ }^{31}$

Selanjutnya, langkah-langkah pengembangan kurikulum berdasarkan pendekatan kompetensi, yaitu mengidentifikasi kompetensi, merumuskan tujuan pendidikan, menyusun pengalaman belajar, menetapkan topik dan subtopik, menetapkan waktu, mengalokasikan waktu, memberi nama mata pelajaran, dan menetapkan bobot SKS.

Dalam penilaian penguasaan kompetensi, ada tiga hal penting yang harus diperhatikan guru, yaitu sebagai berikut.

a. Sasaran penilaian tidak hanya terfokus pada kemampuan tertulis dan lisan saja, tetapi juga tingkat untuk kerja (performance) pelaksanaan tugas yang telah ditetapkan.

b. Kriteria penilaian adalah persyaratan minimal pelaksanaan tugas-tugas.

c. Sasaran utama adalah penguasaan kemampuan (exit requirements) dan bukan pada cara atau waktu pencapaian.

Ciri pendekatan kompetensi yang tidak kalah pentingnya adalah penjaringan dan pengelolaan informasi balikan (feedback) secara teratur untuk melakukan perbaikan secara berkesinambungan sehingga kurikulum memiliki mekanisme untuk memperbaiki diri (regenerative capability), baik tingkat lembaga maupun tingkat nasional.

\section{Pendekatan Sistem (System Approach)}

Sistem adalah totalitas atau keseluruhan komponen yang saling berfungsi, berinteraksi, dan interdependensi untuk mencapai tujuan yang telah ditetapkan. Ciri-ciri sistem adalah adanya tujuan, fungsi, komponen, interaksi dan interdependensi, penggabungan yang menimbulkan jalinan keterpaduan, proses transformasi, umpan balik untuk perbaikan, dan lingkungan. Pendekatan sistem adalah penggunaan berbagai konsep yang

${ }^{31}$ Ibid, 114.

Volume 11 Nomor 1 Maret 2020

Approved: 02-01-2020, Accepted: 15-02-2020, Submitted: 09-03-2020 
serasi dari teori sistem yang umum untuk memahami teori organisasi dan praktik manajemen. Pendekatan sistem terdiri atas beberapa aspek, antara lain: (a) filsafat sistem, yaitu sebagai cara berfikir (way of thingking) tentang fenomena secara keseluruhan, (b) analisis sistem, yaitu metode atau teknik dalam memecahkan masalah (problem solving) atau pengambilan keputusan (decision making), dan (c) manajemen sistem, yaitu aplikasi teori sistem di tengah mengelola organisasi.

Model Intructional Development Institute (IDI) yang dikembangkan oleh University Consortium on Intructional Development and Technology (UCIDT) memiliki langkah langkah pendekatan sistem sebagai berikut.

a. Merumuskan masalah, yang meliputi:

1) Menentukan masalah: analisis kebutuhan, menentukan prioritas, merumuskan masalah.

2) Menganalisis latar: ciri peserta didik, kondisi (hambatan), sumbersumber.

3) Mengatur pengelolaan: analisis tugas, tanggung jawab dan penjadwalan.

b. Mengidentifikasi strategi pemecahan masalah, yang meliputi :

1) Menentukan tujuan pembelajaran: tujuan akhir dan tujuan antara.

2) Menentukan strategi: pendekatan metode, media, dan sumber belajar.

3) Membuat prototipe: bahan-bahan pembelajaran dan evaluasi.

c. Melaksanakan evaluasi, yang meliputi :

1) Uji coba prototipe: melakukan uji coba, mengumpulkan data, dan evaluasi.

2) Analisis hasil uji coba: tujuan pembelajaran, metode dan teknik evaluasi.

3) Penyempurnaan langkah-langkah terdahulu: review, menetapkan, melaksanakan.

\section{Pendekatan Klarifikasi Nilai (Value Clarification Approach)}

Klarifikasi nilai adalah langkah pengambilan keputusan tentang prioritas atas keyakinan sendiri berdasarkan pertimbangan yang rasional, 
logis, sesuai dengan perasaannya dan perasaan orang lain serta aturan yang berlaku. Pendekatan ini menekankan agar peserta didik dapat mengemukakan pendapatnya sendiri tentang isu-isu yang merupakan konflik nilai di samping ada pendapat dari guru.

Ciri pengembangan kurikulum berdasarkan pendekatan klarifikasi nilai, antara lain: (a) peran guru kurang dominan dalam pembelajaran, (b) guru lebih sedikit member informasi dan lebih banyak mendengarkan penjelasan dari peserta didik, (c) guru lebih sering menggunakan metode tanya-jawab, (d) tidak banyak kritik destruktif, (e) kurang menekankan faktor kegagalan dan lebih menerima kesalahan-kesalahan, (f) menanggapi dan menghayati pekerjaan peserta didik, (g) merumuskan tujuan dengan jelas, (h) dalam batas tertentu peserta didik diberi kebebasan untuk bekerja dan bertanggunag jawab, (i) peserta didik bebas mengungkapkan apa yang mereka rasakan, (j) adanya keseimbangan antara tugas kelompok dengan tugas perseorangan, (k) belajar bersifat individual, (l) evaluasi bukan terfokus pada prestasi akademik, tetapi juga proses pertukaran pengalaman, dan (m) peserta didik menemukan sistem nilainya sendiri.

Raths dalam John Jarolimek (1974) mengemukakan langkah-langkah pendekatan klarifikasi nilai sebagai berikut.

a. Kebebasan memilih (bagi peserta didik), yang meliputi:

1) Memilih sesuatu secara bebas menurut kemauan, kesukaan, dan minatnya.

2) Memilih berbagai alternatif yang ada

3) Menentukan pilihan dan pertimbangan yang rasional sesuai dengan pikiran dan pendapat masing-masing.

b. Membina kebanggaan (prizing), di antaranya:

1) Merasakan gembira atas ketepatan memilih

2) Mengukuhkan pilihan sesuai dengan pendapat pada dirinya masingmasing

c. Melaksanakan (acting):

1) Melakukan percobaan atau melaksanakan pilihan

2) Mengulangi perbuatan tersebut dalam kehidupan sehari-hari dan menjadikannya sebagai pola kehidupan. 


\section{Pendekatan Komprehensif (Comprehensive Approach)}

Pendekatan ini melihat, memperhatikan, dan menganalisis kurikulum secara keseluruhan. Semua masalah yang berkaitan dengan kurikulum diidentifikasi secar global oleh pengembang kurikulum. Pengembang kurikulum dapat menetapkan langkah pertama yang akan dilakukan dan apa yang akan dicapai sebagai sasaran dengan merumuskan filsafat pendidikan, visi-visi dan tujuan pendidikan serta sasaran yang ingin dicapai.

\section{Pendekatan yang Berpusat pada Masalah (Problem-Centered Approach)}

Pengembangan kurikulum dengan pendekatan ini dilakukan dengan cara mengidentifikasi berbagai masalah kurikulum secara khusus. Para guru diminta berbagai informasi tentang masalah-masalah, keinginan, harapan, dan kesulitan-kesulitan yang ereka hadapi dalam mata pelajaran, seperti perbaikan cara penampilan, penggunaan multimetode dan media dalam pembelajaran, serta sistem penilaian.

\section{Simpulan}

Definisi dari pendekatan perkembangan kurikulum adalah titik tolak atau sudut pandang secara umum tentang proses pengembangan kurikulum. Terdapat lima pendapat mengenai macam-macam pendekatan perkembangan kurikulum. Pertama, menurut Muhaimin yang terbagi menjadi 4 macam yakni pendekatan subjek akademis, humanistik, teknologis, rekonstruksionisme. Kedua, menurut Wina Sanjaya terbagi menjadi 2 yakni pendekatan top - down, dan grass - roots. Ketiga, menurut H.M. Ahmad terbagi menjadi 2 yakni pendekatan yang berorientasi pada bahan pelajaran, pendekatan yang berorientasi pada tujuan pengajaran. Keempat, menurut Zainal Arifin terbagi menjadi 5 yakni pendekatan kompetensi, system, klarifikasi nilai, komprehensif, berpusat pada masalah. Kelima, menurut Abdullah Idi terbagi menjadi 3 yakni pendekatan yang berorientasi pada bahan pelajaran, pola organisasi bahan, akuntabilitas. 
Dari berbagai macam pendekatan bisa diambil kesimpulan bahwasanya yang paling banyak digunakan dalam mengembangkan kurikulum yaitu pendekatan yang berorientasi pada siswa dan pendekatan subjek akademis (berorientasi pada bahan pengajaran).

\section{DAFTAR PUSTAKA}

Arifin, Zainal.2012. Konsep dan Model Pengembangan Kurikulum. Bandung: PT Remaja Rosdakarya,

Baharuddin \& Makin. 2007. Pendidikan Humanistik: Konsep, Teori, dan Aplikasi Praktis dalam Dunia Pendidikan. Yogyakarta: Ar-Ruzz Media.

Fachruddin.2006. Teknik Pengembangan Kurikulum Penagajaran Bahasa Arab. Yogyakarta: Global Pustaka Utama.

Halimah, Siti. Telaah Kurikulum,

Hamalik, Oemar. 2008. Dasar-dasar Pengembangan Kurikulum. Bandung: PT. Remaja Rosdakarya. 
Idi, Abdullah.2007. Pengembangan Kurikulum Teori dan Praktek. Yogyakarta: Ar-Ruzz Media.

Mudlofir, Ali. 2001. Aplikasi pengembangan KTSP dan Bahan Ajar dalam PAI. Jakarta: Rajawali Pers..

Muhaimin. 2010. Pengembangan Kurikulum Pendidikan Agama Islam di Sekolah, Madrasah dan Perguruan Tinggi. Jakarta: PT. Raja Grafindo Persada.

Nasution, S. 1995.Kurikulum dan Pengajaran. Jakarta: Bumi Aksara.

Sanjaya, Wina. 2008. Kurikulum dan Pembelajaran. Jakarta: Kencana.

Soetopo, Hendyat \& Wasty Soemanto. 1993. Pembinaan dan Pengembangan Kurikulum. Jakarta: Bumi Aksara.

Subandijah. 1993. Pengembangan dan Inovasi Kurikulum. Jakarta: PT. Raja Grafindo Persada.

Sukmadinata, Nana Syaodih. 2004. Pengembangan Kurikulum: Teori dan Praktek. Bandung: PT. Remaja Rosdakarya. 